\title{
Ethnobotany and medicinal uses of folklore medicinal plants belonging to family acanthaceae:An updated review
}

\begin{abstract}
Acanthaceae is a large family of dicotyledonous flowering plants including about 4300 species and 346 genera all over the world. Most are tropical shrubs, herbs and twining vines while some are epiphytes. There is increasing interest about the indigenous medicinal plants for correct identification, taxonomy and medicinal properties. Chemically it contained some important secondary metabolites such as glycosides, flavonoids, alkaloids, triterpenoids, fatty acid methyl esters and fatty acids. These compounds play an important role in many biological reactions and work against many lethal diseases. Leaves, roots and other parts are used as anti-pyrietic, antiinflammatory, anti-spasmodic, antiseptic and antidiabetic. Some other important plants belong to this family are used to treat skin diseases, cough, eye infections, wounds, pneumonia, anti-diarrhea, edema etc. There are only a few examples that underline importance of family Acanthaceae. This medical importance attracted the researchers to explore the various aspects of this family. The medicinal role and significance of the family can hardly be overemphasized. The present review highlights some key features of some important genus of this important plant family and also describes its various conventional and new novel uses in our daily life. By keeping these points the present study will be useful for further research and clinical trials in future study of some new important plant species belong to this important family.
\end{abstract}

Keywords: Acanthaceae; Pharmaceutical uses; Medicinal plants; Secondary metabolites, synthetic medicines
Volume I Issue 2 - 2017

Ibrahim Khan,' Sohail Ahmad Jan,' Zabta Khan Shinwari, ${ }^{1,2}$ Muhammad Ali,', Yasmin Khan,' Taweer Kumar ${ }^{3}$

'Department of Biotechnology, University of Quaid-i-Azam, Pakistan

${ }^{2}$ Pakistan Academy of Sciences, Pakistan

${ }^{3}$ National Agricultural Research Centre (NARC), Pakistan

Correspondence: Zabta Khan Shinwari and Sohail Ahmad Jan, Department of Biotechnology, University, Quaid-i-Azam Islamabad, Pakistan,

Emailsjan.parc@gmail.com, shinwari2008@gmail.com

Received: May 12,2017 | Published: May 18, 2017

\section{Introduction}

\section{General description to medicinal plants of important family acanthaceae}

Plants possess an immense therapeutic potential and a large number of such plants are unexplored to-date. Medicinal plants are source of novel chemical entities that possess beneficial pharmacological and therapeutics properties. These can be used directly or their extracts have been used as starting material in synthesis of pharmaceutical drugs. Traditionally medicinal plants have been used in the preparation of synthetic medicines, even currently in developing world; about $25 \%$ of ingredients in the prescribed modern medicine are derived from extracts of medicinal plants. ${ }^{1-3}$ Family Acanthaceae is a large family of dicotyledonous herbs, shrubs, or twining vines and some are epiphytes only flowering plants. Consist of 4300 species in 346 genera placing it among the top 12 most diverse families of flowering plants in all over the world. The four main centers of distribution are tropical, subtropical and temperate regions of Indonesia and Malaysia, Africa, Brazil and Central America while also found in of Asia. ${ }^{4}$ The systematic position and circumscription of the Acanthaceae has been controversial because of its complexity of habitat range and considerable variation in morphology and genetics. On the basis of pollen morphology several attempts for the classification of Acanthaceae are at the familial, sub-familial, tribal and sub-tribal levels by various workers, were conducted from time to time. ${ }^{5}$

De Jussieu in 1789 subdivided the family on the basis of two to four stamens and recognized genera Acanthus, Barleria, Blepharis,
Dianthera, Dilvaria, Justicia, Ruellia and Thunbergia. ${ }^{6}$ Nees in 1847 undertook the first comprehensive taxonomic treatment of the whole family. He divided the family into two suborders. The Anechmatacantheae comprises two tribes viz. Thunbergieae and Nelsonieae. The Echmatacantheae has nine tribes (Hygrophileae, Ruellieae, Barlerieae, Acantheae, Aphelandreae, Gendarusseae, Eranthemeae, Dicliptereae and Andrographideae. He described a number of genera allied to Stobilanthes Blume, namely Aechmanthera, Stenosiphonium, Phlebophyllum, Endopogon, Leptacanthus, Buteraea, Adenacanthus, Goldfussia and subsequently described three more, namely Triaenacanthus, Mackenziea and Hemigraphis. ${ }^{6}$ Anderson $^{7}$ worked on the enumeration and views regarding the delimitation of the family are different from those of Nees (1847) hence divided the family into three suborders: Thunbergideae, Ruellideae and Acanthideae. Bentham in 1876 divided the family into five tribes viz., Thunbergieae, Nelsonieae, Ruellieae, Acantheae and Justicieae, based on aestivation of corolla, form of corolla, number of seeds and absence or presence of retinacula, with special emphasis to anther morphology. Lindau in 1895 used pollen morphology, particularly in his tribal delimitation, when classifying the family and on the basis of types of fruits, number of ovules and presence or absence of retinacula and their shape. ${ }^{5}$

\section{Worldwide occurrence of family acanthaceae}

The family is known for a wide variety of its tropical and subtropical habitats. Some species are found in temperate regions. ${ }^{4}$ The four main regions of its distribution are Malaysia and Indonesia, Brazil, Africa and Central America. Justicia is the largest genus of 
Acanthaceae, with approximately 600 species, which are found in pantropical and tropical regions. ${ }^{8}$ The detailed information of some important genera of this family is given in Table $1 \&$ Figure1.

\section{General characteristics of family acanthaceae}

Acanthaceae is composed of mainly annual and perennial erect, prostrate or rarely climbing, herbs, shrubs, under shrubs, perennial climbers and rarely small trees. However, it also includes some large trees. Leaves of plants belonging to Acanthaceae are simple, opposite decussate, sinuate, estipulate and usually entire-margined, stems are round to quadrangular with solitary or racemose inflorescence. Flowers are in racemes, spikes or cymes, with large showy in volucral bracts. The fruit is often explosively dehiscent present inside loculicidal capsule shape, Seeds usually borne on hook like retinacula, or retinacula lacking, surface smooth or roughened lacking trichomes or pubescent, and sometimes with hygroscopic trichomes that expand when moistened. ${ }^{9}$

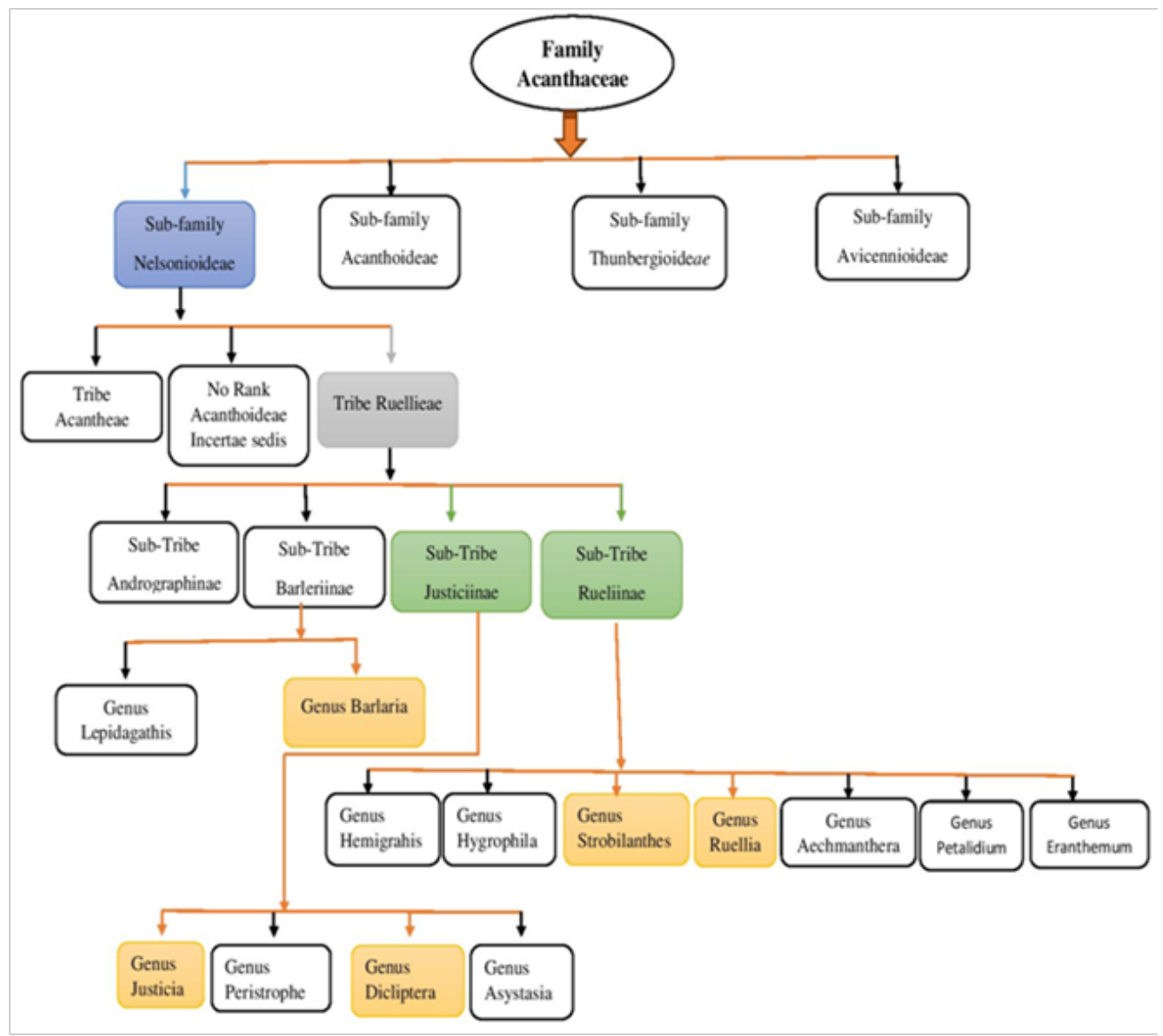

Figure I Classification of some important genera of family Acanthaceae.

Table I Examples of some genera of Acanthaceae found around the world

\begin{tabular}{llllll}
\hline S. No & Genus & S. No & Species & S. No & Genus \\
\hline I & Blepharis Juss. & 7 & Justicia L. & 13 & Asystasia Blume. \\
2 & Lepidagathis Willd. & 8 & Barleria L. & 14 & Petalidium Nees. \\
3 & Aphelandra Roxb. & 9 & Strobilanthes Blume. & 15 & Aechmanthera Nees. \\
4 & Hygrophila Roxb. & 10 & Ruellia L. & 16 & Thunbergia Retz. \\
5 & Dicliptera Juss. & 11 & Crossandra Salisb. & 17 & Graptophyllum Nees. \\
6 & Peristrophe Ness. & 12 & Hemigraphis Nees. & 18 & Eranthemum L. \\
19 & Afrofittonia Lindau & 21 & Filetia Miq. & 23 & Geissomeria Lindl. \\
20 & Ambongia Benoist & 22 & Fittonia Coem. & 24 & Golaea Chiov. \\
25 & Henrya Nees & 27 & Gymnostachyum Nees & 29 & Neriacanthus Benth. \\
26 & Heteradelphia Lindau & 28 & Megaskepasma Lindau & 30 & Vindasia Benoist etc. \\
\hline
\end{tabular}




\section{Habitat}

Plants of family Acanthaceae have been founded in nearly every ecological habitat of tropical to subtropical regions and few species in temperate areas. These occur in moist evergreen and dense or open forests, tropical dry deciduous and scrubby lands forests, on wet fields and valleys, at the sea coast and in swamps. ${ }^{10}$ Acanthus leucostachys and Barleria prionitis show xerophytic adaptation, having reduced spine scent stem and leaves. Based on ecological conditions, Barleria cristata show variation in vegetative parts showing prostate, small leaves and shady areas in erect and large leaves and internodes length and flower size. Species of Strobilanthes show variation in habit e.g. S. asymmetrica, S. clarkei and S. torrentiumare found in high altitude in shady areas. Whereas, some species of Strobilanthes e.g. $S$. auriculata, S. affinis and S. cusia, were, grown in open areas. Justicia procumbens and Rungia pectinata also shows variation in leaf sizes, internodes length and plant height based on ecological conditions. Barleria cristata, Ruellia brittoniana, Hygrophila polysperma, Asystasia gangetica, Salicifolia $H$, pholomoides $H$, H. erecta etc. occupy waste lands and grow as weeds in cultivated fields. ${ }^{5,10}$

\section{Importance of acanthaceae}

\section{Economic values of family acanthaceae}

Plants of Acanthaceae possess an important ecological role like pollinators, butterflies, bees, humming birds, hawk moths, bats and sunbirds depend upon their pollen and nectar for survival.9,11 Species of Acanthaceae can also be used as bio-indicators to proxy the spatial distribution of plant communities. This fact can be detected in the etymology of the word where 'Acan' means 'it washes' as their leaves contain oil and used in laundry. ${ }^{12}$

\section{Medicinal importance of acanthaceae}

Among these the plant species of Acanthaceae play a key role for the treatment of many lethal diseases. It contained many important secondary metabolites as alkaloids, phenols, terpenoids, tannins, quinones, cardiac glycosides, saponins, carbohydrates, flavonoids and proteins that have many therapeutic uses. Some species like Adathoda beddomie, Neelagirianthasis Sp., Justeceae gendurusa, Neelagirianthasis hemitomie, Berleria priorities, Adathoda zylanica and Hemigraphis corolata have the ability to kill or retard the growth of many infectious microbes including dangerous Pseudomonas species. ${ }^{13}$ Several chemicals like 2-propanone, Methylhydrazone, Acetaldehyde, Cyclopentane etc. have been extracted through GC-Mass analysis from important Asteracantha longifolia (L.) Nees species, which are using in many pharmaceutical and cosmetics industries. ${ }^{14}$ The other species Clinacanthus nutans also contained plenty of important bioactive compounds namely flavonoids, glycosides, glycoglycerolipids, cerebrosides and monoacylmonogalatosylglycerol. These compounds have wide range of anti-inflammatory, antiviral, antioxidant, and antidiabetic activities. ${ }^{15}$ Kavitha et al. ${ }^{16}$ also reported the anti-diabitic activity of 25 medicinally important plants from family Acanthaceae. Infusions of leaves of Vesica adhatoda Nees, Dyschorister adicans, Aystasia schimperi, Acanthus eminens, Thunber giaalata, and Dyschoristethum bergiiflora have been used for backache, skin diseases, cough, eye infections, wounds, pneumonia, anti-diarrhea and edema. Leaves paste of Barberia grandicalyx is used for snake bites. Leaves of Acanthus pubescens, Justicia flava and Justicia betonica have been used for ulcers, flu, dry cough and anti-diarrhea. ${ }^{17}$ Infusions of Justicia tranquebariensis have been used for poisonous bites. Leaves of Justicia adhatoda are used traditionally for chest diseases, rheumatism, fever, asthma, pneumonia, tuberculosis, expectorant, diuretic, antispasmodic, antiseptic and to reduce swelling..$^{18}$ Members of the Acanthaceae family like Hygrophila spinosa, Andrographis paniculata, Barleria prionitis and Adhatoda vasica are used traditionally as antipyretic, anti-asthmatic, antiviral and in respiratory diseases. ${ }^{19}$

Genus Ruellia L: This genus of family has significant medicinal importance. Ruellia is a genus of 250 different popular ornamental plants species commonly known as Ruellias. These plants are distributed in tropical regions and temperate regions of world. Many species of the genus contain important constituents such as glycosides, flavonoids, alkaloids and triterpenoids. Because of this property these plants are used in the synthesis of various medicines. Plant extracts of genus Ruellia have anti-hypertensive, antinociceptive, analgesic, antispasmolytic, antioxidant, antiulcer, antidiabetic, antipyretic and anti-inflammatory properties. ${ }^{20}$

Ruellia brittoniana L: Ruellia brittoniana is an herbaceous ornamental perennial herb. Having flowering season from April to November. ${ }^{21}$ Ruellia brittoniana is used for variety of purposes in traditional medicines. In pharmacological investigation, extracts of Ruellia brittoniana were used for cardiovascular screening. ${ }^{20}$ Flavonoids compounds, fatty acid methyl esters and fatty acids were isolated by chromatographic methods. Phytochemical study revealed that Ruellia brittoniana contain 21 components e.g. 5, 2, 3-trihydroxy 7-O-glucoflavone, 5,7,4-trimethoxy 3-O-Rhamnoflavone and 2,2 , 4 , -tetrahydroxy-chalcone. The herbal extract is studied for antiinflammatory and antioxidant effects. ${ }^{22}$

Genus Justicia L: Plants belonging to this genus are distributed in Indonesia, Malaysia, Southeast Asia, India and Pakistan. ${ }^{23}$ It has exhibited to have medicinal properties and fused for the treatment of various diseases and disorders. Respiratory tract diseases have particularly benefited from the ancient times. ${ }^{24}$ Moreover, it has been used for the treatment of gastrointestinal diseases and inflammation, including applications in eczema, malaria, rheumatism, lumber pain and swelling. ${ }^{25}$ Different plants of genus Justicia are utilized for their effects on the central nervous system as hallucinogens, sedatives, somniferous agents, depressors, and treatments of epileptic seizures and other mental disorders. ${ }^{18}$ Plants belonging to this genus have been used as antispasmodic, anti-inflammatory, anti-diabetic, anti-jaundice, fever reducer, anti-bleeding, disinfectant and bronchodilator. ${ }^{26}$ The leaves, flowers and roots of Justicia adhatoda are used in herbal drugs against tubercular activities, cancer and possessed anti-helmintic properties. The leaf infusion is stated to cure glandular tumor, dysentery and diarrhea. ${ }^{27}$

Justicia adhatoda L:Justicia adhatoda is a perennial and evergreen shrub with unpleasant smell and bitter taste. Plants of this genus are widespread throughout the tropical regions of Southeast Asia and growing throughout Pakistan especially in the lower Himalaya. It is commonly known as Malabar nut. ${ }^{28}$ This genus has potent antiperiodic, astringent, diuretic and purgative action. It is a highly valued medicinal plant which is used in the treatment of respiratory diseases like asthma, cough, bronchitis and tuberculosis. ${ }^{29}$ Leaves of this plant has been used as main source of drug, used for the treatment of a wide variety of diseases and disorders, particularly for the respiratory tract ailments like chronic bronchitis, fever, swellings, asthma, pneumonia, malaria, tuberculosis, cold and cough. ${ }^{30}$

Genus Barleria L:During the course of research, Barleria genus was investigated to be the third largest pantropical genus of Acanthaceae 
with more than 300 species worldwide. Plants of this genus are distributed mainly in the subtropical and tropical parts of the world. Traditionally Barleria genus has been classified into two subgenera (Barleria and Prionitis) and seven sections (Barleria, Cavirostrata, Chrysothrix, Stellatohirta, Fissimura, Somalia and Prionitis). ${ }^{31}$ A large number of essential active ingredients and compounds are extracted from Barlerias pecies like terpens, alkaloids, flavonoids, glycosides, phenolics, lignins etc. These compounds have shown effective therapeutic activities against several diseases. Plants belonging to genus Barleria also shows various pharmacological effects such as anti-inflammatory, anthelminthic, antimicrobial, anti-fertility, antioxidant, anti-arthritic, antidiarrhoeal, anti-diabetic, analgesic, diuretic, hepato-protective, cytoprotective, antileukemic, and hypoglycemic properties without any harmful effects. ${ }^{32}$

Barleria cristata L:Plants of Barleria cristata have demonstrated exceptional medicinal as well as ornamental potentials. These are largely perennial shrubs and are located widely in subtropical Himalaya, at a height of $1350 \mathrm{~m}$. It possesses antimicrobial, antiinflammatory, cytotoxic, hepato protective, antioxidant and phytochemicals properties. It has been used traditionally for the treatment of variety of diseases including diabetes and respiratory diseases, anemia, toothache and cough because of its antiseptic activities herbal cosmetics and hair products are exploited from the extracts of the Barleria cristata to promote scalp health and skin. ${ }^{33}$ Solvent extracts of the leaves and bark samples have been displayed to be rich in medicinally valuable class of compounds like saponins, flavonoids and terpenoids. Methanol and acetone extracts of both leaf and bark showed significant cytotoxic and antioxidant activities. ${ }^{34}$

Genus Dicliptera J: Dicliptera genus falls within subtribe Justiciinae of the Acanthaceae. ${ }^{35}$ The taxonomy of this genus is complicated due to the presence of several widespread species complexes in tropical Africa. Furthermore, the genus has been largely neglected taxonomically. This genus has been found to be considerably more diverse there than previously recorded, with several undescribed entities recognizable. ${ }^{36}$

Dicliptera roxburghiana Nees: Members of this genus are commonly known as Kalu. It is distributed in Pakistan, Afghanistan, Nepal, Bangladesh, Bhutan, India and China. Their flowering period ranges from June to October. Medicinal plants of this genus are commonly used for tonic debility and for the treatment of eye diseases. ${ }^{37}$ Dicliptera roxburghiana has a verity of medicinal advantages e.g. its leaves are used in the treatment of cough, gastroenteritis, fever, skin disease and checks bleeding from wounds. The freshly crushed leaves of plants belonging to this genus are used for gentle application on affected portion of body in eczema. ${ }^{30}$

Genus Strobilanthes Nees: Genus Strobilanthes is a morphologically diverse genus of about 350 species distributed throughout South and Southeast Asia, Malaysia, and Northern Australia. ${ }^{38}$ Most of the plants of this genus have anti-inflammatory, antimicrobial, antidiabetic, anticancer and wound healing properties. Extracts of this genus are used in spider poisoning, influenza epidemic, cerebrospinal meningitis, viral pneumonia mumps and acute respiratory Syndrome. ${ }^{39}$

Strobilanthes urticifolia Wall: Herbaceous perennial plants also known as Strobilanthe swallichii and Strobilanthes atropurpureus are found in forest from 2000-3500m in Asian countries. Strobilanthes urticifolia is used in stomach ailments, antiulcer, rheumatism, laxative and diuretic agent. But still there is a need to reveal phytochemical and pharmacological aspects of more number of plants in this plant. ${ }^{7}$

\section{Conclusion}

The plants belonging to family Acanthaceae has a great potential to explore for further studies. Several important plants belong to this family have significant value to control and treat many pathogenic, metabolic, genetic and other lethal diseases. These botanicals possessing medicinal properties might provide a basic raw material for making huge medicinal preparations. Because of its extensive uses all over the world may get extinct. It's therefore necessary of further DNA barcode study to identify new novel species and proper conservational strategies should be initiated regarding this important plant family.

\section{Acknowledgements}

None.

\section{Conflict of interest}

The author declares no conflict of interest.

\section{References}

1. Slier H, Khan A, Khan ZU, et al. Medicinal plants of Udigram, district Swat, Pakistan. Pak J For. 2003;53(1):65-74.

2. Jan SA, Shinwari ZK, Zeb A, et al. Ethnobotany and research trends in Trachyspermum ammi L. (Ajowan) a popular folklore remedy. AmerEurasian J Agric Environ Sci. 2015;15(1):68-73.

3. Qasim M, Khalid M, Sayyed A, et al. Phytochemical potentials and medicinal uses of twenty-four selected medicinal plants from Swabi, Pakistan. J Rural Develop Agri. 2016;1(1):49-58.

4. Wasshausen DC, Wood JRI. Acanthaceae of bolivia. Contributions from the United States National Herbarium. 2004;49:1-152.

5. McDade LA, Daniel TF, Kiel CA. Toward a comprehensive understanding of phylogenetic relationships among lineages of Acanthaceae sl (Lamiales). Am J Bot. 2008;95(9):1136-1152.

6. Abdel-Hameed UK, Tantawy ME, Salim MA, et al. Phenetic analysis of morphological and molecular traits in Acanthaceae Juss. J Biosci Med. 2015;3(3):18-34.

7. Anderson EF. Ethnobotany of hill tribes of northern Thailand. I. Medicinal plants of Akha. Econ Bot. 1986;40(1):38-53

8. Durkee L. Flora Costaricensis: family. Acanthaceae. Field Bot. 1996;1(18):1-87.

9. Fongod AGN, Modjenpa NB, Veranso MC. Ethnobotany of acanthaceae in the mount cameroon region. J Med Plants Res. 2013;7(38):2859-2866.

10. Rahman AM, Rahman MM. Scientia research library ISSN 2348-0416. J Appl Sci Res. 2014;2(2):36-42.

11. Mabberley D. The plant-book: a portable dictionary of the vascular plants second edition; 1997.

12. Mabberley DJ. Mabberley's plant-book: a portable dictionary of plants, their classifications and uses (No. Ed 3) Cambridge University Press; 2008.

13. Prasad MP. Studies on phytochemical analysis and antimicrobial activity of Acanthaceae species. Int J Curr Res. 2014;6(9):8630-8637.

14. Doss A, Rukhshana MS, Rani KP. Identification and properties of Asteracantha longifolia (L.) Nees byGC-MS analysis. $J$ Adv Med Life Sci. 2017;5(1):1-6

15. Alam A, Ferdosh S, Ghafoor K, et al. Clinacanthus nutans: a review of the medicinal uses, pharmacology and phytochemistry. Asian Pac J Trop Med. 2016;9(4):402-409. 
16. Kavitha K, Sujatha, Manoharan S. Antidiabetic potential of acanthaceae family. Int J Pharm Sci Rev Res. 2016;6(1):30-37.

17. Jeruto P, Lukhoba C, Ouma G, et al. An ethnobotanical study of medicinal plants used by the Nandi people in Kenya. J Ethnopharmacol. 2008;116(2):370-376.

18. Hussain M, Ghani A. Herbal remidies used for gastrointestinal disorders in Kaghan valley, NWFP, Pakistan. Pak J Weed Sci Res. 2008;14(34):169-200

19. Krishnaraju AV, Rao TV, Sundararaju D, et al. Assessment of bioactivity of Indian medicinal plants using brine shrimp (Artemia salina) lethality assay. Int J Appl Sci Eng. 2005;3(2):125-134

20. Afzal K, Uzair M, Chaudhary B, et al. Genus ruellia: pharmacological and phytochemical importance in ethnopharmacology. Acta pol pharm. 2015;72(5):821-827.

21. Bishay D, Abdel-Baky A, El-Moghazy S, et al. Macro-and micromorphology of the leaf and stem of ruellia brittoniana leonard cultivated in egypt. Bull Pharm Sci. 2009;32:279-300.

22. Kumar PS, Jayanthi B, Abdul K, et al. Research journal of pharmaceutical, biological and chemical sciences. Res J Pharm Biol Chem Sci. 2002;3(2):752-761

23. Perveen A, Qaiser M. Pollen flora of Pakistan-LXVII: Acanthaceae. Pak J Bot. 2010;42:175-191

24. Atal C, Chandhoke N. Chemistry and pharmacology of vasicine: A new oxytocic and abortifacient: regional research laboratory Jammu; 1980.

25. Jain SK, DeFilipps RA. Medicinal plants of India; Inc, Reference Publications: 1991.

26. Maurya S, Singh D. Quantitative analysis of total phenolic content in Adhatoda vasica Nees extracts. Int J PharmTech Res. 2010;2(4):24032406 .

27. Ayyanar M, Ignacimuthu S. Medicinal uses and pharmacological actions of five commonly used Indian medicinal plants: a mini-review. Iran J Pharmacol Ther. 2008;7(1):107-114

28. Chakraborty A, Brantner A. Study of alkaloids from Adhatoda vasica Nees on their antiinflammatory activity. Phytother Res. 2001;15(6):532534.
29. Jayapriya G, Shoba FG. Phytochemical analysis, antimicrobial efficacy and determination of bioactive components from leaves of justicia adhatoda (Linn). Asian J Plant Sci Res. 2015;5(2):43-51.

30. Sharma M, Ahmad J, Hussain A, et al. Folklore medicinal plants of Mewat (Gurgaon district), Haryana, India. Int J pharm. 1992;30(2):129134.

31. Balkwill MJ, Balkwill K. A preliminary analysis of distribution patterns in a large, pantropical genus, Barleria L.(Acanthaceae). J Biogeogr. 1998. p. 95-110.

32. Gantait A, Barman T, Mukherjee PK. Validated method for estimation of curcumin in turmeric powder. Ind J Trad Know. 2011;10(2):247-250.

33. Amutha K, Doss D. In vitro antioxidant activity of ethanolic extract of barleria cristata L. Leaves. Res J Pharm Phytochem. 2009;1(3):209-212.

34. Gambhire M, Juvekar M, Juvekar A, et al. Evaluation of antiinflammatory and radical scavenging activity of an aqueous extract of Barleria cristata leaves. Planta Med. 2009;75(09):166.

35. Darbyshire I, Vollesen K. The transfer of the genus Peristrophe to Dicliptera (Acanthaceae), with a new species described from eastern Africa. Kew Bulletin. 2007;17(1):119-128.

36. Barker R. Additional. Additional species, new combinations and other notes on Acanthaceae of Australia. J Adelaide Bot Gard. 1996. p. $137-$ 152.

37. Ilyas M, Qureshi R, Shinwari ZK, et al. Some ethnoecological aspects of the plants of Qalagai hills, Kabal valley, swat, Pakistan. Int J Agri Biol. 2013;15(5):801-810.

38. Ismail $\mathrm{M}$, Bagalkotkar $\mathrm{G}$, Iqbal $\mathrm{S}$, et al. Anticancer properties and phenolic contents of sequentially prepared extracts from different parts of selected medicinal plants indigenous to Malaysia. Molecules. 2012;17(5):5745-5756.

39. Terao H. Taxonomic study of the genus Strobilanthes Blume (Acanthaceae): generic delimitation and infrageneric classification; Unpublished thesis submitted for the degree of PhD. Kyoto, Japan: at Kyoto University; 1983. 